RESEARCH PAPER

\title{
Process Development of Low Fat Quarg Cheese Using Fat Replacer
}

\author{
Kadpe, B.B. ${ }^{1}$, Patange, D.D..$^{*}$, Yadav, M.M²., Kamble, D.K²., Memane, C.V ${ }^{2}$ and \\ Kamble, S.S. ${ }^{2}$ \\ ${ }^{1}$ College of Agriculture, Nesri, Kolhapur, India \\ ${ }^{2}$ Faculties of Division of Animal Husbandry and Dairy Science, RCSM College of Agriculture, Kolhapur, India
}

*Corresponding author: patangedeshmukh1@gmail.com

Paper No.: 238

Received: 14-07-2019

Revised: 18-10-2019

Accepted: 25-11-2019

\begin{abstract}
Quarg is a sparkling cheese having a smooth texture, barely bitter flavor and is a type of natural un-ripened and clean cheese. Quarg cheese contains more fat and lacks in whey protein which affects its nutritional quality, therefore it is essential to produce low fat quarg cheese using fat replacers. Initially two fat replacers were tried i.e. carragennan and Simplesse-100 @ 0.5 of quarg and after selecting one, its level was optimized. The optimized product was assessed for its storage stability. During investigation cheese was analyzed for its sensory, physico-chemical and microbial analysis. Maximum score was awarded to the quarg cheese prepared using 0.5 per cent Simplesse-100 when added to quarg after removal of whey. The superior product contained $0.62 \pm 0.03,12.68 \pm 0.08,3.33 \pm 0.02,1.32 \pm 0.04,17.87 \pm 0.02 \%$ fat, protein, lactose, ash and total solids, respectively whereas, its $\mathrm{pH}$ was $4.36 \pm 0.06$. During the storage, there were significant $(\mathrm{p}<0.05)$ differences in change in all the sensory qualities, proximate composition of fat replacer added quarg cheese.
\end{abstract}

Keywords: Quarg cheese, fat replacer, storage study, sensory and proximate analysis

Fermentation is the oldest and most economical method in food preservation. It has been well documented that fermentation enhances mineral bioavailability and digestibility of proteins and carbohydrates as well as improves sensory qualities of the product. Numbers of fermented dairy products are being prepared all over the world including dahi, yoghurt, lassi and cheese. Cheese is a well known milk product that is valued for its nutritional superiority. Several types of chesses are manufactured with wide ranging flavours, texture, and forms. There are more than 2000 varieties of cheese, although many have little differences. The most popular varieties of cheese are cheddar, mozzarella, feta, cottage and quarg cheese.
Quarg is a sparkling cheese having a smooth texture and barely bitter flavor. It is a protein-rich, milky white or slight yellowish acidic coagulated and is a type of natural un-ripened and clean cheese which is most popular in countries like Germany. It is made from pasteurized skim milk or entire milk by incorporating Streptococcus cremoris and Leuconostoc citrovorum or any other starter culture and with a little quantity of rennet enzyme. Precipitation of the casein proteins occurs due to the combined action of these substances.

How to cite this article: Kadpe, B.B., Patange, D.D., Yadav, M.M., Kamble, D.K., Memane, C.V. and Kamble, S.S. (2019). Process Development of Low Fat Quarg Cheese Using Fat Replacer. Int. J. Food Ferment. Technol., 9(2) 139-148.

Source of Support: None; Conflict of Interest: None 
The obtained coagulum is subsequently cooked and allowed draining the whey to get quarg. The moisture content in quarg is more $(82 \%, w / w)$ (Yadav et al. 2019).

On an average, quarg cheese contain 11 per cent fat, 18 per cent protein, 4.5 per cent carbohydrate and 1.4 per cent ash. Presence of $18 \%$ protein is significant of quarg cheese, however presence of 11 per cent fat may increase its production cost and decreases consumption. As incidence of various chronic diseases such as elevated blood pressure, obesity and atherosclerosis is increasing rapidly and it has been found to be associated with high fat intake by people (Tiwari, 2005). Saturated fats are found mainly in foods of animal origin like whole milk, butter, cheese and also in coconut and palm oil. Nutrition experts recommend that the total intake of dietary fat should not exceed 30 percent of daily energy intake. Health conscious people look for the ways to improve nutritional habits without sacrificing psychological satisfaction so peoples prefer low fat diet. This has led to the increasing demand for low fat or no fat dairy food products with good taste. However, development in fat reduced products is associated with a number of difficulties. Defatted dairy products most often have a number of flaws: too hard, resilient of coarse consistency, poor taste and aroma (Simrnova, 2014).

In case of cheese, reduction in fat in also adversely affects its textural, functional and sensorial attributes such as rubbery texture, poor meltability, bitter taste, lack of flavor and undesirable colour (Alfonso and Norma, 2008). Few substances have been identified which can be incorporated in low fat food to improve its sensory properties, without affecting the aroma and flavor of foods formulated with the fat replacer.

Therefore, fat replacer possesses such potential to provide an alternative to high fat product to meet the expectation of the consumers' requirement for healthy food (Tiwari, 2005). Accordingly, food industries have focused on the production of low fat /low calorie, high fiber as a functional food in response to the public interest in the last couple of decades (Agarwal et al. 2016).
Fat replacer is a substance which chemically resembles fats, proteins or carbohydrates and possesses certain desirable physical or organoleptic properties of fat (Ahmed et al. 2015). These are of low calorie and possess some of functional properties of fat (Chavan et al. 2016). Fat replacers can be successfully utilized in the development of low fat cheese, yoghurt, spreads, frozen dessert, cream cheese and sour cream. It gives a sense of lubricity and creaminess in these products. Considering the health benefits of low fat quarg cheese and functional properties of fat replacer, the present investigation was undertaken. The objective of this study was to determine the effects of fat replacers on the physico-chemical, sensory and microbial quality of low-fat quarg cheese and also to find the storage stability of the product.

\section{MATERIAL AND METHODS}

Buffalo milk was procured from Dairy Farm, Rajarshi Chhatrapati Shahu Maharaj College of Agriculture, Kolhapur. Starter culture LF 40 was procured from National Collection of Dairy Culture, ICAR-NDRI, Karnal, Haryana (India) and microbial rennet was procured from CHR Hansen Ltd. Mumbai. Simplesse-100 from CP Kelco, Denmark and Carragennan from Marine Hydrocolloids Cochin, Kerala (India) were utilized as fat replacer.

\section{Preparation of low fat quarg cheese}

Initially quarg cheese was prepared as per protocol developed by Patange et al. (2018) for spiced quarg cheese with suitable modification. Buffalo milk was separated to get the milk of desired fat per cent as per treatment. The milk was heated to $80^{\circ} \mathrm{C}$ for 10 min in SS made cheese vat of size $25 \times 16 \times 16 \mathrm{~cm}$ and then, cooled to $28-30^{\circ} \mathrm{C}$ followed by inoculation of LF-40 starter culture @1 per cent and allowed to hold in undisturbed condition for at least one hr. to lower down the $\mathrm{pH}$ to 6.2-6.3. Subsequently microbial rennet was added @ $0.5 \mathrm{~g}$ per $100 \mathrm{ml}$ of milk and mix was incubated for $14-16 \mathrm{hr}$ at $31^{\circ} \mathrm{C}$ to achieve the $\mathrm{pH}$ of 4.9 to 5.0. Obtained firmed curd was then, cut using both vertical and horizontal MS framed knife with nylon wire followed by cooking it by keeping 
cheese vat in water bath. The heating process was accomplished slowly upto $65^{\circ} \mathrm{C}$ (rate of rising $1^{\circ} \mathrm{C} /$ 2 min of time). After cooking the expelled whey was drained out by hanging the coagulum in doubled layered cotton muslin cloth to get quarg. The process is shown in Fig. 1.

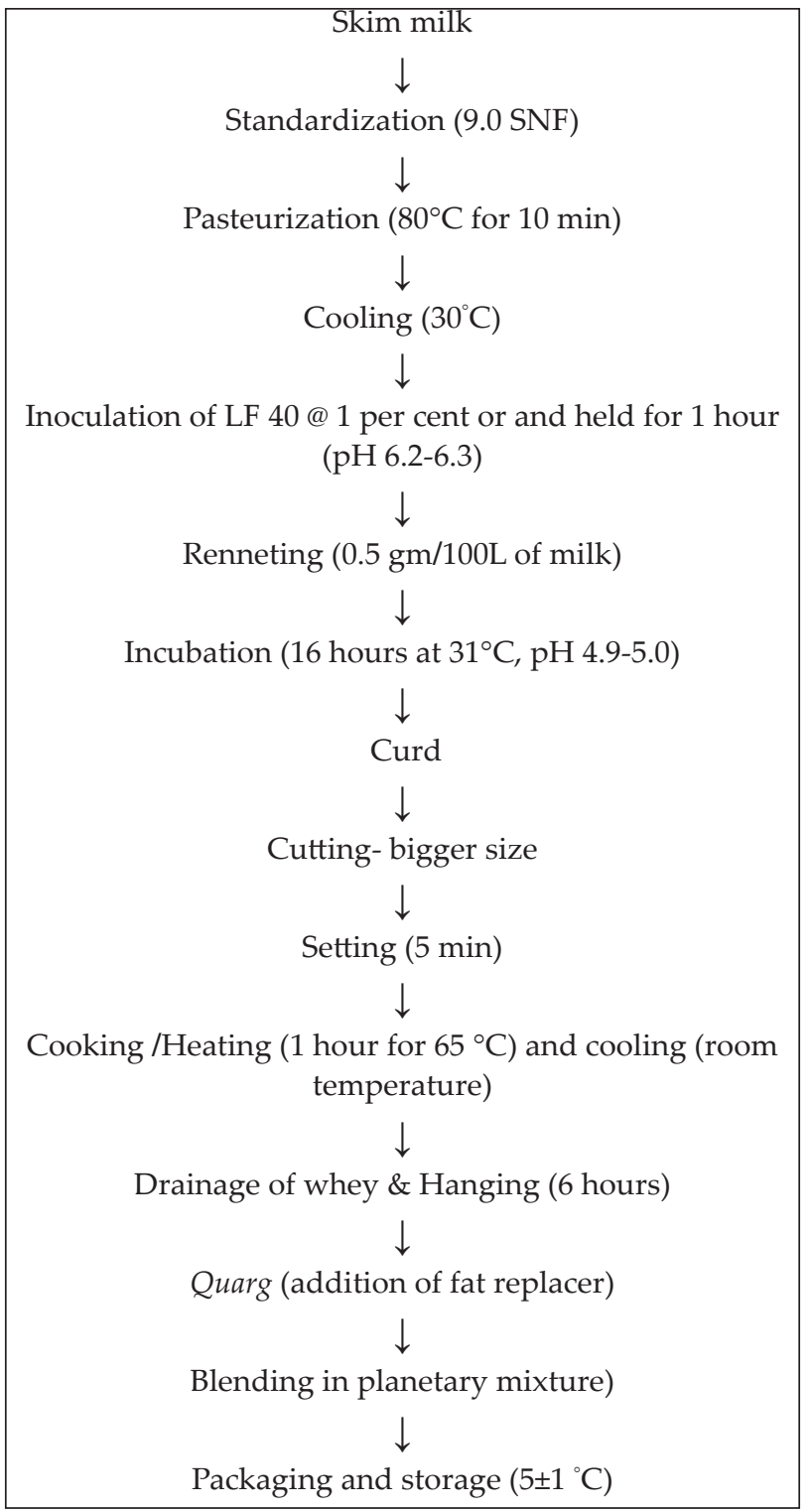

Fig. 1: Flow diagram of low fat quarg cheese added with fat replacer

Selection of type and stage of fat replacer in quarg cheese

Carragennan $\left(\mathrm{T}_{2}\right)$ and Simplesse-100 $\left(\mathrm{T}_{3}\right)$ fat replacer were mixed in the quarg cheese (@0.5\% of quarg) after the drainage of whey and compared with quarg cheese made from standardized milk $\left(\mathrm{T}_{0}\right)$ and skim milk $\left(T_{1}\right)$. One fat replacer was selected on the basis of sensory evaluation of quarg cheese.

\section{Optimization of level of fat replacer in quarg cheese}

From above trail, the selected fat replacer was tested @ $0.2\left(\mathrm{~S}_{1}\right), 0.4\left(\mathrm{~S}_{2}\right), 0.6\left(\mathrm{~S}_{3}\right)$ and $0.8 \%\left(\mathrm{~S}_{4}\right)$ of quarg and compared with the quarg prepared from standardized milk $\left(\mathrm{S}_{0}\right)$ was added at following level of quarg and analyzed for sensory and physico chemical properties. The best level of fat replacer was optimized on the basis of sensory evaluation.

\section{Storage stability study of low fat quarg cheese}

The optimized product $\left(\mathrm{P}_{2}\right)$ was packed in food grade plastic sterilized container of $100 \mathrm{~g}$ size and stored at $5 \pm 1^{\circ} \mathrm{C}$ for storage stability study and compared with control $\left(\mathrm{P}_{1}\right)$ i.e. low fat quarg cheese without addition of fat replacer. The samples were evaluated after 3 days of interval for changes in sensory, physicochemical and microbial qualities till their sensory acceptability.

\section{Analysis of quarg cheese}

Sensory evaluation was carried out with scoring test by five panelists who were the faculty members of the department. The panelists were selected on the basis of their interest in sensory evaluation of cheese The different samples of cheeses were evaluated for flavour, colour and appearance, spreadability, body and texture and overall acceptability using a score from ' 1 ' to ' 9 '. Approximately, 15 to $20 \mathrm{~g}$ of each sample was presented to panelists, to clean palates of panelists between samples potable drinking water and bread were provide. Panelists were also requested to tick-mark the defects on the scale in order to determine the reasons of decrease in scores. The samples of cheeses were analyzed for proximate composition as per AOAC, (2000); during the storage period along with sensory and chemical analysis microbial load in terms of total plate count, yeast and 
. P Kadpe et al.

mould coliform and count were enumerated as per manual of dairy bacteriology, ICAR (1982).

\section{Statistical Analysis}

All data are presented as mean \pm SD for three replicates for each sample. The experimental design was completely randomized design (CRD) in factorial arrangement using three replications as suggested by (Snedecor and Cochran, 1994).

\section{RESULTS AND DISCUSSION}

Effect of type of fat replacer on sensory properties of low fat quarg cheese

The diagrammatic representation (Fig. 1) of score for colour and appearance of low fat quarg cheese was significantly $(\mathrm{p}<0.05)$ affected by the level of fat replacer. The highest score $(8.25 \pm 0.03)$ was obtained by quarg cheese where in simplesse-100 was mixed. For this treatment, judges made the comments that the product had shiny and creamy colour with uniform appearance. The effect of simplesse- 100 was at par with the quarg produced from $4.5 \%$ milk. Nurcan and Mustafa (2004) also reported that the colour of the low-fat fresh kashar cheeses containing fat replacers was different from that of low-fat control cheese. Moreover, the use of simplesse D-100 corrected all appearance defects which were determined in low fat fresh kashar cheese. Further they reported that the low-fat control cheese had a more translucent surface and denser colour than full-fat cheese. Fat replacers, can also act as light-scattering centers and increase the opaqueness of low fat cheese (Mcmahon et al. 1996). It was observed that the score of body and texture obtained was significantly $(p<0.05)$ highest $(8.35 \pm 0.02)$ for quarg cheese under treatment $\mathrm{T}_{3}$ (Fig. 2 ) and it possessed soft body and smooth texture. The quarg prepared from skim milk was comparatively compact and had firm body and coarse texture. When tapioca starch and lecithin as a fat replacer were used to produce a reduced-fat Feta cheese, the hardness and yield loss values decreased and the moisture content were increased (Sipahioglu et al. 1999). The addition of some hydrocolloids, mainly carrageenan, may replace the addition of fat and emulsifying salts. The quarg prepared by addition of carragennan recorded significantly $(\mathrm{p}<0.05)$ highest score for spreadability (score $8.21 \pm 0.02$ ) as compared to simplasee-100 (Fig. 3). Processed cheese with added carragennan was found to be hard and impossible to spread was reported by Cernikova et al. (2010). However, improvement in spreadability score of carragennan added quarg cheese over cheese made from skim milk is supported by the facts of Blaszak et al. (2018) who reported that even small amounts of carragennan can increase cheese firmness and maintain cheese structure after cheese curd heating. Further, they mentioned that any modifications in cheese composition can destroy the natural cheese structure, but the addition of carragennan can be useful for creating modified cheese-like products with desirable attributes. The good quality quarg has characteristics like clean and mildly acidic flavour and has optimum sourness and acidic taste as good as Chakka and yoghurt. The effect of all treatments were statistically different $(p<0.05)$ with respect to flavour score, the quarg prepared by addition of Simplesse-100 recorded highest score for flavour (score $8.10 \pm 0.02$ ), followed by the quarg prepared from the milk containing $4.5 \%$ fat (score $8.00 \pm 0.05$ ). Improvement in flavor score was in accordance with the facts reported by Smirnova (2014), who found that the advantages of protein fat imitators are not only to increase the protein content but also to add a creamy flavor to nonfat products. The flavour score of quarg cheese with carragennan and Simplesse-100 were close to each other (Fig. 4). The mean flavour scores SimplessesD-100 added low fat cheese were closer scores to full-fat cheese was informed by Nurcan and Mustafa (2004). Among the four treatments under study, the quarg prepared from skim milk had lowest score which could be due to low-fat cheeses commonly present a poor aroma and a typical flavors caused by the lack of aromatic compounds that are produced by lower levels of lipolysis. In addition, their typical high moisture content cause excessive growth of the starter culture, which accelerates acid production, resulting in bitter flavors (Diamantino et al. 2014). Cheeses with lower fats usually have less 


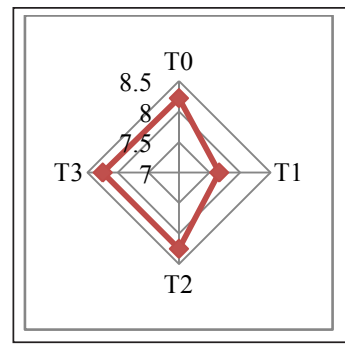

Fig. 1: Effect of type of fat replacer on colour and appearance score

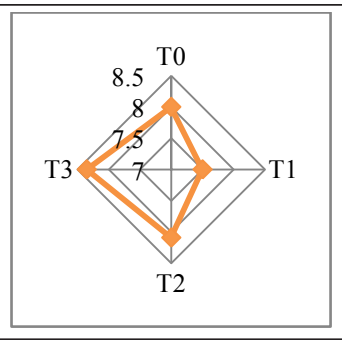

Fig. 2: Effect of type of fat replacer on body and texture score

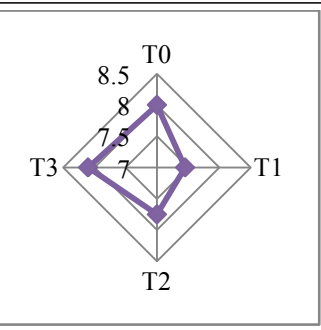

Fig. 3: Effect of type of fat replacer on flavour score

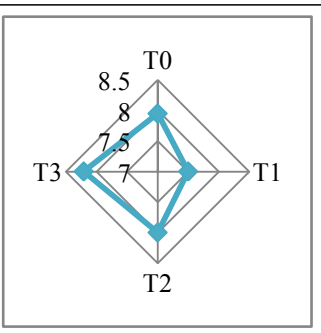

Fig. 4: Effect of type of fat replacer on spreadability score

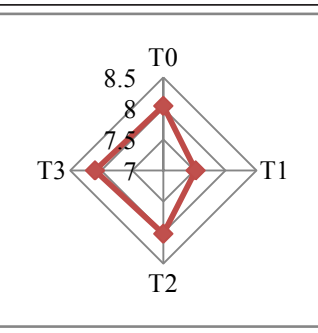

Fig. 5: Effect of type of fat replacer on overall acceptability score pronounced flavour, possibly because of its dilution in reduced and low-fat cheeses because of excessive moisture retention, and the fats in cheese are responsible for most of the flavors, therefore when fats are decreased, the cheeses flavour was decreased by as described earlier Tareq et al. (2016).

The effect of type of fat replacer was also examined on the overall acceptability of quarg cheese (Fig. 5) The overall acceptability score ranged from $7.52 \pm 0.04$ to $8.10 \pm 0.02$. The maximum score was obtained by the product containing Simplesse-100, it may be because of higher water holding capacity of carragennan resulted in too firm body of product along with resistance to spread and poor mouthfeel. The difference in the score of $T_{0}$ and $T_{1}$ were supported by the findings of Gokhan et al. (2004) who reported that in full-fat and low-fat white pickled cheeses added with fat replacer showed that, as the fat content of cheese milk decreased, fat in total solids, total solids and cheese yield of white pickled cheese significantly decreased but the moisture and total nitrogen values significantly increased which affected the sensory qualities of cheese. Tareq et al. (2016) also studied the effect of Kappa Carrageenan, locust bean and Xanthan gums had on sensory score of Domiati cheese and found that higher scores on the evaluated attributes of cheese were to the moisture content enhancement, thereby resulting in a decrease in the differences noted between the sensory evaluation of full and low-fat cheese. After looking into these results, in subsequence study the product was prepared by addition of Simplesse-100 as a fat replacer.
Effect of level of fat replacer on sensory attributes of low fat quarg cheese

The score for colour and appearance of quarg cheese were significantly affected by the level of Simplesse-100. The highest score $(8.45 \pm 0.03)$ was awarded to quarg wherein Simplesse-100 was added @ 0.6 per cent (Table 2). For these treatment, judges made the comments that the product had shiny and slight creamy colour with uniform appearance. With the increasing quantity of WPC in quarg the improvement in coloour and appearance was also observed by Patange et al. (2018) and the colour was shining and slight creamy colour with uniform appearance. Statistically, the colour and appearance difference within $S_{2^{\prime}} S_{3^{\prime}}$ and $S_{4}$ were at par with each other. The quarg prepared by addition of Simplesse-100 at 0.6 per cent recorded highest score for body and texture $(8.50 \pm 0.06)$. Lowest score was noticed for skim milk quarg cheese $(7.50 \pm 0.02)$. Statistically the body and texture difference within $S_{3}$ were at par with $S_{2}$ and $S_{4}$. The score for these three treatments were in narrow range and ranged from 8.35 to 8.50 . It is clearly illustrated from the Table 1 that at 0.6 per cent level of addition Simplesse-100 the score for spreadability of quarg was highly significant $(p<0.05)$ compared to the treatments. The spreadability score for So, $\mathrm{S}_{1}, \mathrm{~S}_{2}, \mathrm{~S}_{3}$ and $\mathrm{S}_{4}$ were $7.46 \pm 0.02,8.07 \pm 0.03,8.21 \pm 0.02,8.30 \pm 0.05,7.90 \pm 0.01$. The score within $S_{1}, S_{2}, S_{3}$ were at par with each other.

The good quality quarg has characteristic clean and mildly acidic flavour and has optimum sourness and acidic taste as good as like chakka and yoghurt. It was observed that treatment differences are statistically 
Table 1: Effect of level of fat replacer on sensory attributes (score) of low fat quarg cheese

\begin{tabular}{llllll}
\hline \multirow{2}{*}{ Treatment } & \multicolumn{5}{c}{ Sensory attributes } \\
\cline { 2 - 5 } & Colour and appearance & Body and texture & Spreadability & Flavor & Overall acceptability \\
\hline $\mathrm{S}_{0}($ Control $)$ & $7.66^{\mathrm{a}} \pm 0.02$ & $7.50^{\mathrm{a}} \pm 0.02$ & $7.46^{\mathrm{a}} \pm 0.02$ & $7.50^{\mathrm{a}} \pm 0.02$ & $7.53^{\mathrm{a}} \pm 0.03$ \\
$\mathrm{~S}_{1}(0.2)$ & $7.92^{\mathrm{b}} \pm 0.02$ & $8.10^{\mathrm{b}} \pm 0.05$ & $8.07^{\mathrm{b}} 0.03$ & $8.05^{\mathrm{b}} \pm 0.03$ & $8.05^{\mathrm{b}} \pm 0.04$ \\
$\mathrm{~S}_{2}(0.4)$ & $8.32^{\mathrm{c}} \pm 0.02$ & $8.40^{\mathrm{c}} \pm 0.05$ & $8.21^{\mathrm{c}} \pm 0.02$ & $8.30^{\mathrm{c}} \pm 0.03$ & $8.32^{\mathrm{c}} \pm 0.05$ \\
$\mathrm{~S}_{3}(0.6)$ & $8.45^{\mathrm{c}} \pm 0.03$ & $8.50^{\mathrm{cd}} \pm 0.06$ & $8.30^{\mathrm{c}} \pm 0.05$ & $8.40^{\mathrm{d}} \pm 0.03$ & $8.39^{\mathrm{c}} \pm 0.02$ \\
$\mathrm{~S}_{4}(0.8)$ & $8.40^{\mathrm{c}} \pm 0.02$ & $8.35^{\mathrm{d}} \pm 0.01$ & $7.90^{\mathrm{b}} \pm 0.01$ & $8.50^{\mathrm{e}} \pm 0.05$ & $8.28^{\mathrm{b}} \pm 0.05$ \\
\hline $\mathrm{SEm}$ & 0.01 & 0.01 & 0.09 & 0.01 & 0.01 \\
\hline $\mathrm{CD}(\mathrm{p}<0.05)$ & 0.16 & 0.15 & 0.27 & 0.04 & 0.10 \\
\hline
\end{tabular}

Mean \pm of four replication within column followed by same letter are non-significantly different at $p<0.05$.

Table 2: Effect of fat replacer physico-chemical properties* of low fat quarg cheese

\begin{tabular}{lllllll}
\hline \multirow{2}{*}{ Treatment } & \multicolumn{5}{c}{ Physico-chemical properties of low fat quarg cheese } \\
\cline { 2 - 7 } & Fat (\%) & Protein (\%) & Lactose (\%) & Ash (\%) & TS (\%) & pH \\
\hline $\mathrm{S}_{0}$ (control) & $0.45^{\mathrm{a}} \pm 0.02$ & $12.00^{\mathrm{a}} \pm 0.02$ & $3.00^{\mathrm{a}} \pm 0.15$ & $1.01^{\mathrm{a}} \pm 0.13$ & $16.46^{\mathrm{a}} \pm 0.02$ & $4.47^{\mathrm{d}} \pm 0.03$ \\
$\mathrm{~S}_{1}(0.2)$ & $0.53^{\mathrm{b}} \pm 0.03$ & $12.33^{\mathrm{b}} \pm 0.05$ & $3.17^{\mathrm{b}} \pm 0.03$ & $1.20^{\mathrm{b}} \pm 0.06$ & $17.17^{\mathrm{b}} \pm 0.06$ & $4.45^{\mathrm{c}} \pm 0.05$ \\
$\mathrm{~S}_{2}(0.4)$ & $0.45^{\mathrm{a}} \pm 0.02$ & $12.50^{\mathrm{c}} \pm 0.05$ & $3.25^{\mathrm{b}} \pm 0.01$ & $1.29^{\mathrm{c}} \pm 0.04$ & $17.54^{\mathrm{c}} \pm 0.02$ & $4.42^{\mathrm{b}} \pm 0.01$ \\
$\mathrm{~S}_{3}(0.6)$ & $0.62^{\mathrm{d}} \pm 0.03$ & $12.68^{\mathrm{d}} \pm 0.08$ & $3.33^{\mathrm{b}} \pm 0.02$ & $1.32^{\mathrm{d}} \pm 0.04$ & $17.87^{\mathrm{d}} \pm 0.02$ & $4.36^{\mathrm{a}} \pm 0.06$ \\
$\mathrm{~S}_{4}(0.8)$ & $0.69^{\mathrm{e}} \pm 0.05$ & $12.74^{\mathrm{e}} \pm 0.06$ & $3.40^{\mathrm{b}} \pm 0.05$ & $1.37^{\mathrm{e}} \pm 0.01$ & $18.08^{\mathrm{e}} \pm 0.02$ & $4.34^{\mathrm{a}} \pm 0.02$ \\
\hline SEm & 0.01 & 0.03 & 0.02 & 0.03 & 0.01 & 0.02 \\
\hline $\mathrm{CD}(\mathrm{p}<0.05)$ & 0.03 & 0.10 & 0.07 & 0.10 & 0.03 & 0.02 \\
\hline
\end{tabular}

* Mean \pm of four replication within column followed by same letter are non-significantly different at $p<0.05$.

significant at 5 per cent level of significance. The perusal of data from showed that the quarg prepared by addition of Simplesse- 100 at 0.8 per cent was recorded highest score for flavour $(8.50 \pm 0.05)$. The flavour score for $S_{1}, S_{2}$, and $S_{3}$ were $8.05 \pm 0.03$, $8.30 \pm 0.03$ and $8.40 \pm 0.03$, respectively. Slightly sourish with an expressed flavor and odor of pasteurization with a slight cooked flavor of whey proteins was noticed in protein based fat replacer products by Smirnova (2014). From overall acceptability scores, it is clear that quarg prepared by addition of 0.6 per cent Simplesse-100 had scored significantly highest score $(8.39 \pm 0.02)$, followed by quarg of $S_{2}(8.32 \pm 0.05)$ treatments. Statistically there were no significant differences between $\mathrm{S}_{2}$ and $\mathrm{S}_{3}$. Study results of Nurcan and Mustafa (2004) indicated that SimplessesD-100 can improve the instrumental texture properties and sensory properties of low-fat fresh kashar cheese.
Fuangpaiboon and Kijroongrojana (2017) studied the effects of Simplesse ${ }^{\circledR} 100$ on the sensory and physical properties of reduced-fat $(4 \%)$ and low-fat $(2 \%)$ coconut-milk ice cream in comparison with a control containing $8 \%$ fat. The reduced-fat ice cream with Simplesse 100 added exhibited the sensory characteristics (firmness, iciness, melt-down, mouthcoating, sweetness, coconut flavour and skimmed milk powder flavour) mostly similar to the control.

Effect of level of fat replacer on physico-chemical properties of low fat quarg cheese

The effect of level of fat replacer on physicochemical properties of low fat quarg cheese were also measured and presented in Table 2. The average fat content of low fat quarg was $0.45 \pm 0.02,0.53 \pm 0.03$, $0.45 \pm 0.02,0.62 \pm 0.03$ and $0.69 \pm 0.05$ for $S_{0^{\prime}} S_{1}, S_{2}, S_{3}$ and $S_{4}$, respectively. The slight but significant rise 
in the fat content of quarg cheese may be because of presence of fat in Simplesse as reported by Smirnova, (2014). The highest $(12.74 \%)$ level of protein content was noticed in low fat quarg cheese added with 0.8 percent Simplesse-100. It was observed that protein content showed gradual but significant $(\mathrm{p}<0.05)$ increase in the level of Simplesse-100.Contradictory findings were reported by Tareq et al. (2016) who reported that adding mixture of hydrocolloids as fat mimetic didn't significantly affect the cheese protein content. However, lactose content in quarg cheese $\mathrm{S}_{1}, \mathrm{~S}_{2}$, and $\mathrm{S}_{3}$ were at par with each other and values for these chesses were $3.17 \pm 0.03,3.25 \pm 0.01$ and 3.33 \pm 0.02 , respectively. The Average ash content (\%) in quarg were $1.01 \pm 0.13\left(\mathrm{~S}_{0}\right), 1.20 \pm 0.06\left(\mathrm{~S}_{1}\right), 1.29 \pm 0.04$ $\left(\mathrm{S}_{2}\right), 1.32 \pm 0.04\left(\mathrm{~S}_{3}\right)$, and $1.37 \pm 0.01\left(\mathrm{~S}_{4}\right)$. It was observed that the ash content of low fat quarg cheese gradual increase with increase in level of Simplesse-100. It was observed that the TS content showed gradual increased with the increase in level of Simplesse- 100 . Average TS was ranged from $16.46 \pm 0.02$ to $18.08 \pm 0.02$ $\%$. Comparatively higher TS content in Sudanese low fat cheese was reported by Elkhidier and Hamid (2017) and Patange et al. (2018) in WPC increased quarg cheese. The acidity of low fat quarg in was ranged from $1.68 \pm 0.09$ to $1.80 \pm 0.02$ (\% LA) whereas $\mathrm{pH}$ was ranged from $4.47 \pm 0.03$, to $4.34 \pm 0.02$.

\section{Effect of storage period on sensory attributes (score) of low fat quarg cheese}

As the storage period was increased, then score of colour and appearance decreased in both the cheeses. Initially the score for colour and appearance for control sample and quarg with fat replacer was $7.66 \pm 0.02$ and $8.50 \pm 0.05$, respectively (Fig. 6). However, the rate of decline was higher in $\mathrm{P}_{1}$ than $\mathrm{P}_{2}$ cheese. Controlled sample was best up to 9 days while fat replacer quarg sample was up to 12 days and after that the microbial (yeast and mould) visible growth was observed in the product. The decline in body and texture scores during storage (Fig. 6) may be attributed to increase in the free moisture content in the product and contributed to the softness of the product. The average flavour score was decreased from 8.50 to 6.25 for $\mathrm{P}_{2}$ (Fig. 7). Smirnova (2014) recorded decreasing flavour score of dairy product added with Simplesse- 100 had the main taste defect, which is intensified during storage, is a caramelization flavor, which is associated with a higher content of whey protein. Improvement in flavour score of low-fat kashar cheeese added with Simplesse- 100 up to 22 days of storage was observed by Nurcan and Mustafa (2004).

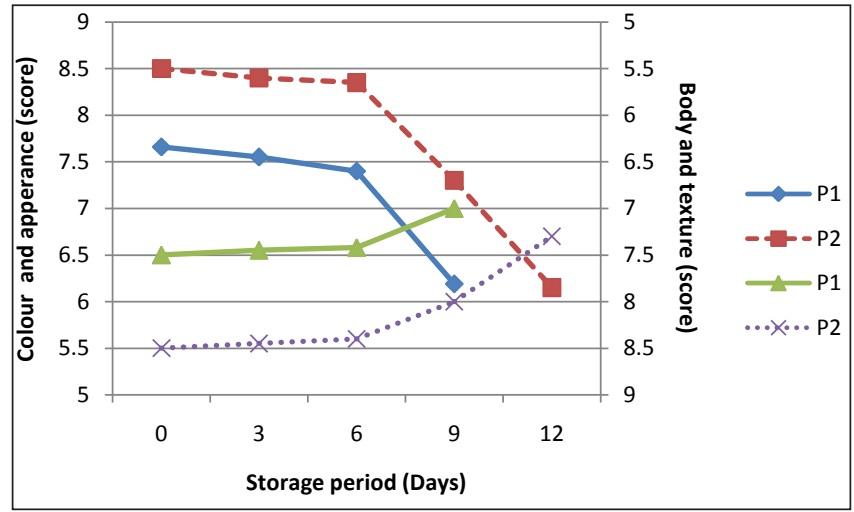

Fig. 6: Changes in color and appearance and body and texture score of quarg cheese during storage

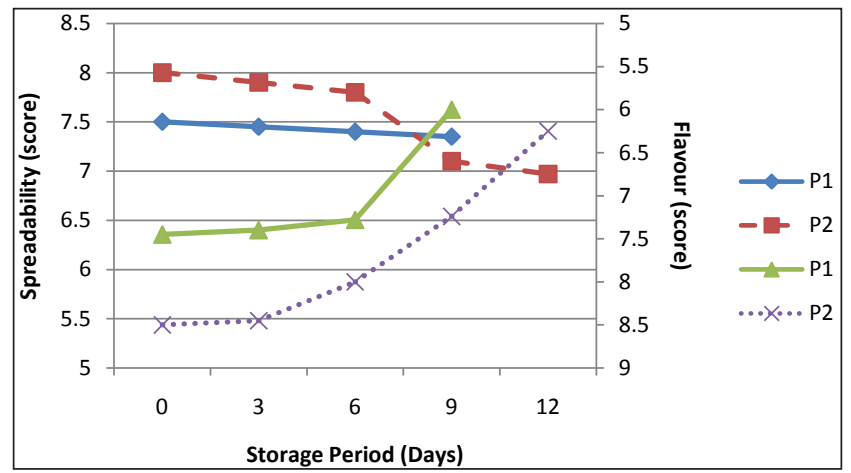

Fig. 7: Changes in spreadability and flavour score of quarg cheese during storage

During storage, development of stale bitter and metallic flavour was observed by Sachdeva et al (1993) in quarg cheese. Similar type of observation was also recorded by Kadiya et al. (2014) and who observed a prominent purification odour in quarg cheese due to yeast and mould growth. Spreadability score was ranged from $8.00 \pm 0.05$ to $6.97 \pm 0.3$ for same sample. The score for overall acceptability on last day of storage period were $6.55 \pm 0.01$ and $6.35 \pm 0.01$ for $P_{1}$ and $\mathrm{P}_{2}$ samples (Fig. 7). Similar result was obtained by Yadav (2015) where author reported that the quarg 
sample stored under refrigeration $\left(4^{\circ} \mathrm{C}\right)$ was same in appearance up to six days, thereafter the quality decreased slightly and remained acceptable for 10 days.

\section{Effect of storage period on physico-chemical properties of low fat quarg cheese}

Fat content (\%) of freshly prepared control sample and Simplesse-100 added quarg cheese was found to be $0.47 \pm 0.03$ and $0.50 \pm 0.02$. The fat content of $P_{2}$ sample was reduced to $0.32 \pm 0.01$ during $12^{\text {th }}$ day of storage (Fig. 8). The decrease in fat content of quarg cheese during storage period might be attributed to the fact of lipolysis activity in the product. Similarly the protein content of $\mathrm{P}_{1}$ and $\mathrm{P}_{2}$ sample shown significant $(p<0.005)$ differences throughout the storage period. The protein content in $\mathrm{P}_{2}$ sample was decreased up to $11.28 \pm 0.08$ on $12^{\text {th }}$ day of storage (Fig. 8). Decrease in protein content in low-fat kashar cheese was also observed by Nurcan and Mustafa (2004). It was revealed from the Fig. 9 that there was a slightly decrease in lactose content during storage. The overall reduction in lactose content from $3.00 \pm 0.05$ to $2.76 \pm 0.04$ in $\mathrm{P}_{1}$ while $3.25 \pm 0.04$ to $2.63 \pm 0.05$ in $\mathrm{P}_{2}$. The average per cent ash content of control low fat quarg cheese was $1.00 \pm 0.01$ on 0 days whereas ash content in quarg of blended with fat replacer on same day was $1.29 \pm 0.01$. The ash content of the quarg of blended with fat replacer increased to $1.45 \pm 0.01$ (Fig 9). Hence, it is clear that there was significant increase during storage period. The initial Total solid content in $\mathrm{P}_{1}$ and $\mathrm{P}_{2}$ was $17.18 \pm 0.02$ and $17.54 \pm 0.02$ per cent, respectively. The $\mathrm{P}_{2}$ sample showed the significant decrease in total solid over a storage period. The average total solid per cent recorded was $17.46 \pm 0.04$, $17.44 \pm 0.02,17.40 \pm 0.02$ and $17.36 \pm 0.04$ per cent on $3^{\text {rd }}$, $6^{\text {th }}, 9^{\text {th }}$ and $12^{\text {th }}$ day of storage respectively (Fig. 10). Somewhat similar trend in TS content of with and without fat replacement fresh low-fat kashar cheese was reported by Nurcan and Mustafa (2004). The result of Vajihel et al. (2012) are closely associated with the present finding where in they reported that moisture content was significant low or fat replacer added sample.

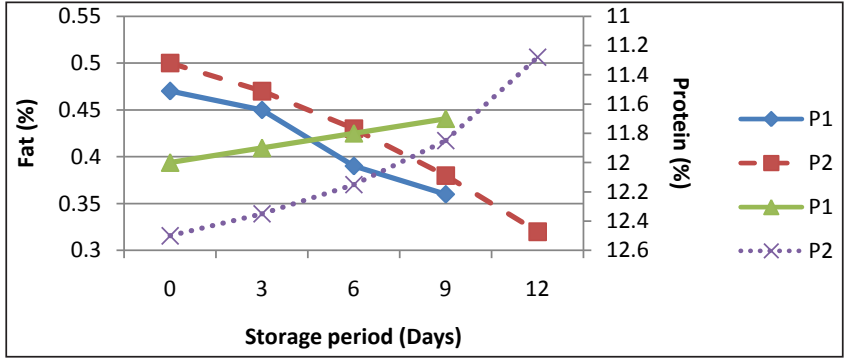

Fig. 8: Changes in fat and protein content (\%) of quarg cheese during storage

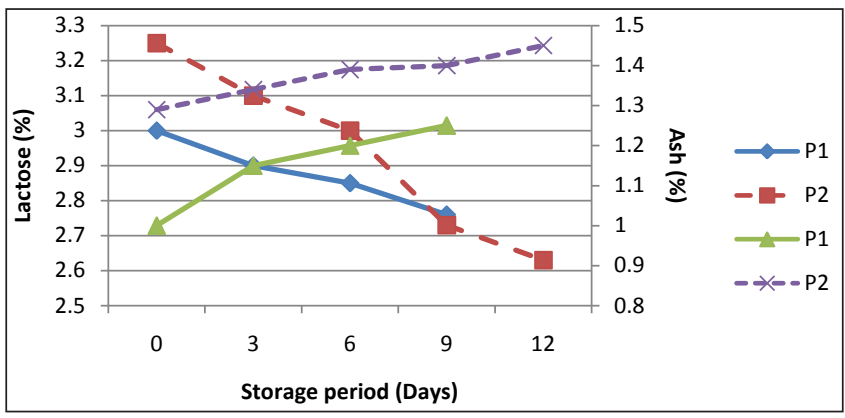

Fig. 9: Changes in lactose and ash content (\%) of quarg cheese during storage

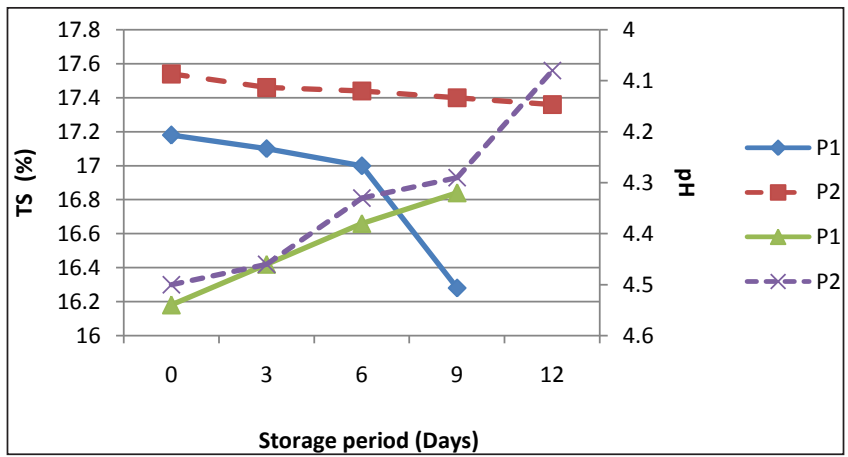

Fig. 10: Changes in TS (\%) and pH of quarg cheese during storage

The $\mathrm{pH}$ of fresh quarg cheese sample was $4.54 \pm 0.01$ $\left(\mathrm{P}_{1}\right)$ and $4.50 \pm 0.05\left(\mathrm{P}_{2}\right)$. It decreased during the storage period in all the samples but at different rate. The effect was found to be statistical significant $(p<0.05)$ on each day of evaluation. In the $P_{1}$ sample the rate of decrease was rapid as $\mathrm{pH}$ decreased from initial value of $4.54 \pm 0.01$ to $4.46 \pm 0.02,4.38 \pm 0.02$, and $4.32 \pm 0.03$ after 3,6 and 9 days respectively. In case of $\mathrm{P}_{2}$ cheese, $\mathrm{pH}$ was decreased from $4.50 \pm 0.05$ to $4.46 \pm 0.01,4.33 \pm 0.02,4.29 \pm 0.04$ and $4.08 \pm 0.12$ after 3,6 , 
9 and 12 days of storage respectively. Shekhar (2014) and Patange $e t$ al. (2018) also observed decrease in $\mathrm{pH}$ of quarg during storage.

\section{Effect of storage on microbial load of low fat quarg cheese}

The rate of growth of microorganism in control sample was significantly $(\mathrm{P}<0.05)$ faster in $\mathrm{P}_{1}$ than $\mathrm{P}_{2}$. The average of SPC count was observed to be $1.85 \pm 0.01$, $2.25 \pm 0.01$, and $3.60 \pm 0.05 \log 10 / \mathrm{g}$ on $3^{\text {rd }}, 6^{\text {th }}$ and $9^{\text {th }}$ day of storage respectively. In case of quarg cheese with fat replacer, the average SPC count observed was $2.16 \pm 0.01,3.22 \pm 0.01,3.42 \pm 0.02,3.65 \pm 0.01 \log 10 / g$ on $3^{\text {rd }}, 6^{\text {th }}, 9^{\text {th }}$ and $12^{\text {th }}$ day of storage respectively. In treatment $\mathrm{P}_{1}$ the average $\mathrm{YMC}$ on $6^{\text {th }}$ and $9^{\text {th }}$ day of storage was observed to be $0.32 \pm 0.01$ and $0.54 \pm 0.02$ $\log 10 / g$. There was no effect of addition of fat replacer on coliform count in quarg cheese and it compared with control during storage.

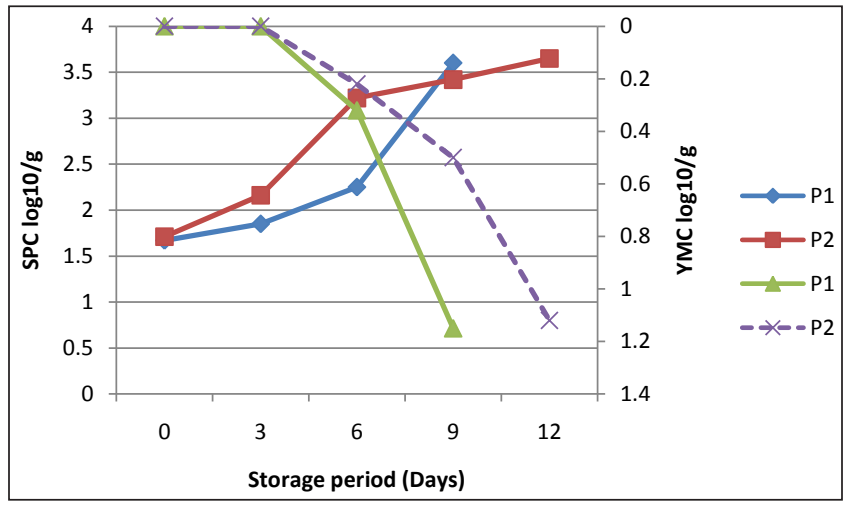

Fig. 11: Changes in SPC and YMC of quarg cheese during storage

\section{CONCLUSIONS}

From the study it is concluded that compared to carragennan, use of simpleese-100@0.6\%, as a fat replacer found to be the most suitable in terms of sensory qualities of low fat quarg cheese. The optimized quarg cheese scored $8.45 \pm 0.03,8.50 \pm 0.06$, $8.30 \pm 0.05,8.40 \pm 0.03$ and $8.39 \pm 0.02$ for colour and appearance, body and texture, spreadability, flavour and overall acceptability, respectively. Whereas, it contained $0.62 \pm 0.03,12.68 \pm 0.08,3.33 \pm 0.02,1.32 \pm 0.04$ and $17.87 \pm 0.02 \mathrm{fat}(\%)$, protein $(\%)$, lactose $(\%)$, ash $(\%)$ and TS (\%), respectively. The product had $4.36 \pm 0.06$ $\mathrm{pH}$. The experimental low-fat quarg cheese added with fat replacer could be stored upto 12 days without any marked deteoration.

\section{ACKNOWLEDGEMENTS}

The authors thankfully acknowledge CP Kelco, Denmark and Carragennan from Marine Hydrocolloids Cochin, Kerala (India) for supply of fat replacers, used in the present investigation.

\section{REFERENCES}

Aggarwal, D., Sabikhi, L. and Sathish Kumar, M.H. 2016. Formulation of reduced-calorie biscuits using artificial sweeteners and fat replacer with dairy-multigrain approach. NFS Journal, 2: 1-7.

Ahmed, M.A., Amal, M.M., El-Nimer., Mostafa, M.A. and Omar, H. 2015. Effect of Fat Replacer or Transglutaminase on the Quality of Low-Fat Gouda-Like Cheese. World J. of Dairy and Food Sci., 10 (2): 170-180.

Alfonso, T. and Norma, G. 2008. Effect of $\kappa$ - and $\lambda$-Carrageenans as Fat-Replacers in Low-Fat Oaxaca Cheese, International Journal of Food Properties, 11(3): 656-668.

AOAC, 2000. Association of Official Analytical Chemists. Official Methods of Analysis, $16^{\text {th }}$ ed. Washington, DC, USA, pp. 20-49.

Blaszak, B., Gozdecka, G. and Shyichuk, A. 2018. Carrageenan as a functional additive in the production of cheese and cheese-like products. Acta Sci. Pol. Technol. Aliment., 17(2), 107-116.

Cerníkova, M., Bunka, F., Pospiech, M., Tremlova, B., Hladka, K., Pavlínek, V. and Brezina, P. 2010. Replacement of traditional emulsifying salts by selected hydrocolloids in processed cheese production. Int. Dairy J., 20: 336-343.

Chavan, R.S., Khedkar, C.D. and Bhat, S. 2016. Fat replacer. The Encyclopedia of Food and health. 2: 589-595.

Diamantino, V.B., Beraldo, F.A., Sunakozawa, T.N. and Penna, A.L.A. 2014. Effect of octenyl succinylated waxy starch as a fat mimetic on texture, microstructure and physicochemical properties of Minas fresh cheese. LWT - Food Science and Technology, 56: 356-362.

Elkhidier, I.E.A. and Hamid, O.I.A. 2017. Effect of different levels of fat on the chemical composition and sensory characteristics of Sudanese low-fat cheese during storage. J. of Agril. and Vet. Sci., 10(2): 2319-2312.

Fuangpaiboon, N. and Kiroongrojana, K. 2017. Sensorial and Physical properties of coconut-milk ice cream modified with fat replacer. Maejp. Int. J. Sci. Technol., 11(2): 133-147. 
Gokhan, K., Gulderen, O., Ozer, K. and Harun, U. 2004. Effect of some fat replacers on chemical, physical and sensory attributes of low-fat white pickled cheese. Food Chemistry, 88(3): 381-388.

ICAR, 1982. Manual of dairy bacteriology, Indian Council of Agricultural research Publication.

McMahon, D.J., Alleyne, M.C., Fife, R.L. and Oberg, C.J. 1996. Use of fat replacers in low-fat Mozzarella cheese. J. Dairy Sci., 79: 1911-1921.

Nurcan, K. and Mustafa, M. 2004. Textural, melting and sensory properties of low-fat fresh kashar cheeses produced by using fat replacers. Int. Dairy J., 12: 365-373.

Patange, D.D., Shinde, S.V., Chavan, D.S., Kamble, D.K. and Memane, C.V. 2018. Process Standardization of whey protein enriched spiced quarg cheese. Int. J. Curr. Microbiol. App. Sci., 7(06): 1349-1358.

Shekhar, S. 2014. Development of quarg type cheese by replacing milk fat with vegetable oil. M. Tech. Thesis (unpublished), National Dairy Research Institute, Karnal, Haryana.

Sipahioglu, O., Alvarez, V.B. and Solano-Lopez, C. 1999. Structure, physico-chemical and sensory properties of feta cheese made with tapioca starch and lecithin as fat mimetics. Int. Dairy J., 9(11): 783-789.
Smirnova. 2014. Current trends in non-fat dairy production. Foods and Raw Materials, 2(2): 47-52.

Snedecor, W.G. and Cochron, G.W. 1994. Statistical methods. East-West press Pvt. Ltd., New Delhi.

Tareq, A., Ahmed, H., Amal, H. and Khaled, E. 2016. Utilizing the Functions of Hydrocolloids as Fat Mimetic to Enhance the Properties of Low-fat Domiati Cheese. J. Food Process Techno., 7: 11

Tiwari. 2005. Fat replacers for healthy foods. In lecture compendium on recent development in health foods and nutraceuticals. Organized by DT Division, National Dairy Research Institute, Karnal, pp. 110-115.

Vajiheh, F., Khadijeh, P., Mohammad, D. and Mahmud, H. 2012. Chemical characteristics of low-fat whey less cream cheese containing insulin as fat replacer. European J. of Experimental Biology, 2(3): 690-694.

Yadav, P., Chauhan, A.K. and Singh, R.B. 2019. Quarg cheese Characteristics, preparation, and recent advances as a functional food. In The Role of Functional Food Security in Global Health Edited by Ram B. Singh, Ronald Ross Watson and Toru Takahashi, Academic press, pp. 395-408. https://doi.org/10.1016/B978-0-12-813148-0.00023-2

Yadav, R.S. 2015. Optimization of processing parameters and extension shelf life of quarg type of thick yoghurt. Sunsari technical College Journal, 2(1): 38-43. 